\title{
Colonial Medicine and Cholera: Historicizing Victorian Medical Debates in J.G. Farrell's The Siege of Krishnapur
}

\author{
Prashant Maurya and Nagendra Kumar
}

Indian Institute of Technology (IIT) Roorkee, India

\begin{abstract}
The present paper examines the use and description of colonial medicine for cholera and its practices in J.G. Farrell's historical novel, The Siege of Krishnapur (1973). The paper shows that by engaging the two doctors stationed at the British residency in Krishnapur in a debate, Farrell contextualises an episode in British medical history to foreground popular medical beliefs on the aetiology of cholera and its treatment prevalent in nineteenth century Britain. The paper then argues that Farrell's critique of an outdated medicinal theory and welcoming of the scientific future of colonial medicine simultaneously is an attempt to reinstate the position of "civilised medicine" in colonial India. It further establishes a vital link between Farrell and cholera by bringing in contemporary contexts, and discusses how cholera served as a dual tool to not only satisfy his compulsive interest in disease and doctors but also his aspirations for historical creativeness.
\end{abstract}

Keywords: cholera, J.G. Farrell, colonial medicine, residency, miasma, germ theory, siege.

\section{Introduction}

The present discussion concerns the contextualisation of an episode in British medical history by James Gordon Farrell in his novel The Siege of Krishnapur, to bring out popular medical beliefs on cholera and its treatment prevalent in nineteenth century Britain, using the traditional literary technique of dialogue. Published in 1973 and awarded the Booker Prize in the same year, it is the second novel of his Empire Trilogy ${ }^{1}$. It is based on the siege of the British residency ${ }^{2}$ in Lucknow, India, during the First War of Independence ${ }^{3}$ in 1857 . The siege lasted for approximately five months, with hundreds of British and loyal natives inside the residency, fighting to save their lives in a hand to mouth situation. The event occupies a unique place in the history of 1857. Indian historian R. C. Majumdar considers the event as, "[T]he most amazing episode in the whole military history of the mutiny" (58) because of the unequal contest between the besieged and the rebels, and the former's ultimate victory over the latter. Historian John Pemble writes, "The little band in the Residency did more than make history" (qtd. in Thorpe 180) for it truly reiterated and glamorised British strength and its extraordinary perseverance during exceptional times. The event has triggered not only the historical but also the literary imaginations. For instance, A. L. Tennyson's poem "The Defence of Lucknow" (1879) recalls the enduringness of the British against the siege through boasting, ethnocentric lines, "Handful of men as we were, we were English in heart and limb/Strong 
with the strength, of the race to command, to obey, to endure" (46-47). G. A. Henty briefly situates the adolescent protagonists, Dick and Ned, inside the residency of Lucknow in his novel In Times of Peril (1881).

In Farrell's novel, the fictional Krishnapur residency has substituted for the Lucknow residency. The novel engages with the adventures of the British characters stationed inside the residency amidst misery, menace, conflict, horror, disease and death. The tragedy of the residency is heightened due to the outbreak of cholera, which causes many casualties, including the death of the head civil surgeon of the residency. His death offers many interesting insights into colonial understanding of and medicine for cholera, which this paper intends to discuss. Using the trope of the deadly and devastating disease cholera, Farrell, through this novel, not only intervenes into the nuances of colonial medicine but highlights the tussle within western medicine which was making its way into India, later to be canonised as "civilised medicine".

In post-colonial scholarship, "Colonial medicine" is treated as a subject of critical enquiry. "Historians have hotly debated the extent to which medicine helped in the establishment of colonial power and hegemony in India" (Saini 528). Colonial medical discourse is significant in understanding the complex issue of colonialism. Colonial knowledge of India focuses strongly on diseases, epidemics, deaths, and the indigenous medical system. Cholera is one of the most deadly diseases that is linked with India. In colonial discourse, the native Indians were perceived as dwellers of mud, defecating in the open, living in unhygienic surroundings. At the same time, their bodies were defined as filthy, untidy, vile and prone to diseases. Uncleanliness and unsanitary living conditions are the adjectives that the British colonisers deemed fit to define the lives of their poor Indian subjects, in contrast to their own clean bodies and hygienic living conditions. In this context, the "body" of the colonised acted as a site of contestation between the coloniser and the colonised. It is through the politics and understanding of the biological body that the colonisers were successful in propagating western medicine, which was one of their hegemonic agendas. By intervening in the nuances of responses of a body suffering from a disease, the British attempted mastery over the colonised body. In this regard, David Arnold argues, "Colonialism used - or attempted to use - the body as a site for the construction of its own authority, legitimacy, and control" ( Colonising the Body 8).

The British perception of the body controls their treatment towards the bodies. By controlling the diseases, they attempted to control the body. For instance, the intervention in the body through vaccination of diseases like smallpox and cholera allowed them to demonstrate their alleged paternalistic duty towards their colonial subjects. Later, the state-sponsored drives for cleanliness and sanitation were also an attempt to interfere in the colonised body. Advancements in medical sciences enabled the British to "pride themselves on their scientific understanding of disease causation and mocked what they saw as fatalism, superstition and barbarity of 


\section{SARE, Vol. 57, Issue 2 | 2020}

indigenous responses to disease" (Arnold, Imperial Medicine 7). By successfully establishing themselves as being better at controlling diseases, the new "civilised medicine" was encouraged over the indigenous medical systems and made available in the colonies. The targets were the uppercaste elites of India who allied themselves with European education and culture. According to Kumar, "An influential section of the Indian society was thus coming under western medical influence” (167). Later through the introduction of the Indian Medical Services, colonial medicine was made available to every stratum of Indian society through Indian doctors trained in European medical practice. In this way, colonial medicine not only acted as a tool in expanding the British colonial regime but has also been used by the British to display superiority and rationality over the indigenous medical systems of India, like Ayurveda.

However, in recent scholarship, "colonial medicine" has become an important site from which to criticise the western paternal notion of excellence and hegemony. According to McCleery, in the twenty-first century "medicine in the colonies slowly began to be seen in a more critical light as a method of subjugating indigenous peoples with disruptive and often unhealthy consequences" (153). Critics such as Ramasubban (1982, 1988) and others have criticised the British colonial policies because they overlooked the medical problems arising out of the tropical diseases in India. Literary authors have also engaged in medical history and colonial medicine to subvert the paternalistic notion of western medicine. For instance, Amitav Ghosh has overtly presented the inharmonious relationship between colonial and indigenous medical practices in his novel The Calcutta Chromosome (1995). We see that Mangala in the novel has her folk understanding of malaria, which is contrary to the colonial treatment of malaria. Her medical practice is intertwined with religion, and hence, diseases are associated with deities. On the contrary, the colonial medical method relies on practicality and rebuffs any religious interference.

During the early and mid-nineteenth century, Britain witnessed rapid societal changes. Morrell notes, "Crucial changes in both British science and British society took place then and there about" (184). A shift in the content of medical ideas (Rosenberg 678) is also visible at the same time. The prevalent miasma theory of disease ${ }^{4}$ underwent critical scrutiny in the scientific and medical community. However, it persisted for a few more decades until a "relationship between a causative microbe and a disease" (Karamanou et al. 61) was established. This early phase of the germ theory of disease, which acts as a rebuttal of miasma theory, holds a central place in Farrell's novel and is key to the discussion of cholera (believed to be caused by miasma). Among the novels in the trilogy, it is the most "medically crowded" novel, crammed with instances of health problems, disease, medicine, and death. Critics like Crane and Livett (1997) and McLeod (2007) suggest Farrell's biographical account as the backdrop of his obsession with disease and medicine in his novels. This is partly true as Farrell had a medical 


\section{SARE, Vol. 57, Issue 2 | 2020}

history, which was an essential phase in his life. He was afflicted by polio and remained uncured till his death. However, his preoccupation with cholera, in particular, as the paper will argue, is an outcome of an altogether different experience. Unlike Ghosh, Farrell is more interested in the clash over medicine within one group, i.e., the colonisers. He potentially historicises the medical debates about the aetiology of cholera and its treatment, and critiques the fractured medical practices of those times.

In the present paper, it is argued that Farrell's critique of an outdated medical theory and welcoming of the scientific future of British medicine simultaneously is an attempt to reinstate the position of "civilised medicine" in colonial India. We further establish a vital link between Farrell and cholera by bringing in the contemporary cultural context, and discuss how cholera served as a dual tool to not only satisfy his obsession with disease and doctors but also his aspirations for historical creativeness, which he sought by writing historical fiction about the British Empire.

\section{Cholera, Company and India}

When East India Company surgeons began in the eighteenth century to practice their craft among the troops and traders in South Asia, they encountered new diseases, some of which affected delicate Europeans differently from locals - though that was hard to gauge, since their practice among these others was occasional and unrepresentative ... it was assumed that the place modified bodily processes. (Hamlin 35)

The East India Company met with a slew of challenges when it established its position in India. The country was not only a place of great fortune but also equally a place of "constant hardship and deadly risk" (Goodman, "Unpalatable Truths" 205). New diseases and the tropical Indian climate were of utmost concern to the British. James Beattie observes, “[T]he British were becoming increasingly pessimistic of ever being able to successfully acclimatise to India" (90). They considered the climate of India detrimental to their health and responsible for the new diseases, such as cholera. E. M. Collingham considers the experiences of British folk in India as "intensely physical" not only because of the climatic contrast between the two countries but also due to the "ever-present specter of illness and death" (qtd. in Goodman, "Unpalatable Truths" 206).

Cholera, a tropical disease, was the most prominent among the deadly trinity ${ }^{5}$ of diseases which defines the history of epidemic diseases in nineteenth-century colonial India (Arnold, Colonising the Body 10). It is not possible to pinpoint the exact place of origin of cholera, but according to the widespread belief, its earliest traces have been found in India. According to Pollitzer, "Bengal, in India has been the cradle, if not the original home 


\section{SARE, Vol. 57, Issue 2 | 2020}

of cholera" (427). David Arnold writes about its beginning that it "spread beyond its 'home' in deltaic Bengal to cover much of the subcontinent, and from India to much of Asia and Europe in the course of the next 15 years" (qtd. in Harrison, Public Health, chapt. 4). He considers cholera, "too potent a factor in the viability and profitability of empire for the Company" (Colonising the Body 27) as it not only annihilated substantial British and local population in India but also had a negative impact on the Company's revenue.

Cholera produced "widespread panic, prompting measures to manage not only the disease itself but also the volatilities of the panic-stricken population" (Almeida 57). To quote, Lester, the panic of cholera was "woven into the fabric of everyday life for colonisers or the Company's men" (235; my italics). The Company faced massive loss of lives among its army personnel and civilians in India due to cholera. MacLeod and Lewis comment, "Cholera took far more lives of British soldiers in India than did the battles themselves" (44). As it was a tropical disease, and new to the British, its cure was unavailable in colonial medicine. As Pamela Gilbert notes, for many years, cholera "as a medical category, was far from clear and unified" (qtd. in Almeida 58). The mortality rate due to cholera was also very alarming. According to Wakimura, this tropical disease "killed about 15 million people from 1817 to 1865 " (2-3). This figure underlines the devastating nature of cholera, which was more than enough to send the nineteenth-century public into frenzy. It also reemphasises the need for a strong focus on cholera in the medical debate of the time.

Colonial development projects like means of transportation (Railways and Ships) had contributed significantly in spreading cholera within as well as outside India. The presence of Mr Worseley and Mr Ford, the railway engineers, in the novel signifies the presence of a railway project in Krishnapur. The railway in India, brought by the British, not only increased the mobility of people from one location to another but also the mobility of contagious diseases. The Company troops, mercantile goods, labourers, and slaves travelled extensively through the railway and also carried the diseases from one place to another sporadically. The port cities developed by the British for commercial ventures were also very crucial in the propagation of cholera. Cities like Madras, Bombay, Calcutta, etc. have functioned as a "disease entrepot". They were the "point of departure as well as point of entry for the pathogens" (Arnold, Colonising the Body 10). Calcutta, where the high command office of the Company was situated, features prominently in the novel. The arrival and departure of the British from homeland to colony and vice versa is a routine in the novel. Public movements, maritime trades, military commutes and overseas labour transactions all enhanced the possibility of diseases becoming epidemics. These movements have played an essential role in the transoceanic exchanges of epidemic diseases like cholera (Arnold, Colonising the Body 10). These ambitious projects like railway, meant chiefly to increase and tighten the colonial grip by 


\section{SARE, Vol. 57, Issue 2 | 2020}

intervening into every remote part of India through a colonial railway nexus, offered the British not only access to the fortunes of India but also to its diseases, which were unknown to British medical science.

It was only when cholera reached Britain and other parts of the world that it attracted the attention of Epidemiologists and medical practitioners. According to Platizky, cholera in Britain was a "shock disease" that catalysed phobic reactions (533). Mushtaq makes a pertinent remark that cholera prevailed in India long before but "[g]ained the focus of medical services due to its serious impact on the troops and officers of the Company; otherwise, it was a disease of poor people" (10). Some temporary measures were taken to stop cholera, however, "lack of scientific understanding of how the disease spread, the poorly developed public health systems and, perhaps most importantly, prevailing social attitudes and complacency towards the conditions of poor and vulnerable populations allowed cholera to return time and again" (Lee 8). There was contention for a long time on how cholera spreads. It continued to fascinate contemporary medical experts and scientists till the late nineteenth century, but nothing except a "vague awareness of the problem of 'tropical disease' and isolated attempts to overcome it" (Harrison, "Tropical Medicine” 317) emerged.

\section{Cholera; causes and treatment: The Victorian Medical Debate}

The British East India Company had employed European-trained surgeons to serve the staff of the Company. Initially, the scope of the surgeons' work was limited to looking after military personnel, but later on, it also covered civilian medical requirements. In Farrell's novel Dr Dunstaple, the civil surgeon, and Dr McNab, the junior regimental surgeon, shoulder the responsibility of the medical needs of Krishnapur residency. Being a senior and head civil surgeon, Dunstaple has some hold in the residency as well as in Krishnapur. He had long been looking after the health of the British community in Krishnapur, from prescribing medicines for ailments to attending childbirths. Young MacNab, on the other hand, is new to Krishnapur; he is Dunstaple's deputy and takes charge in his absence. The two doctors represent two different schools of medicine of the 1850s. Dunstaple is a practitioner of a school of medicine which heavily relies on "miasma theory" of diseases, while young McNab belongs to the school of medicine which believes in the "germ theory" of diseases. The germ theory of disease, however, was in its initial stages and thus did not have much acceptance. This contrast in medical beliefs causes a tussle between the two on the issue of cholera, as the two popular assumptions about cholera during that time were, it is either airborne (based on "miasma theory") or water-borne (based on "germ theory").

In the midst of the year 1857, the uprising of the Indians posed a threat to the lives of the British people across India. Taking cognisance of the deteriorating law and order situation in Krishnapur, the Collector, Mr Hopkins, orders the provision of shelter to every European and loyal native inside the residency to ensure their 
safety and well being. The accommodation of the British, Eurasians and few loyal natives inside the residency causes congestion. The residency eventually turns into a battlefield where the rebels and the besieged fight against each other for the next few months. The ongoing war between the rebellious native soldiers and the Company's soldiers to save the residency causes death every day. On Collector's command, the bodies of the non-British people are dumped outside the back boundary wall of the residency where they pile up, rotten and decaying. The British attitude towards the dead bodies of the colonised is pathetic irrespective of religion. In Hindu and Sikh traditions, the physical body contains the soul (the Atman), which is to be respected and therefore should, after death, be cremated upon a pyre; in Islam, the priest buries the dead body while offering prayers. The act of dumping the dead soldiers and civilians of different faiths without giving them proper burial shows the disrespect of the British authority towards the bodies of the colonised. The treatment of the British dead is completely different; whether Catholic or Protestant, they are cremated observing every appropriate rite, inside the residency campus.

During the monsoon season, rain heightens the foul smell of the decaying bodies. Eventually, one of the residents is diagnosed with cholera. Dunstaple is duty-bound to provide medical care to his patients and to save them from cholera. Unfortunately, he looks at them with what Foucault terms the "medical gaze". The bodies of the patients become objects of analysis when they come under his observation, leading towards greater power for himself. The medical gaze, Foucault argues, allows the doctor to penetrate the body of a patient to dig out the hidden truth, which only he can understand. This gaze subsequently provides him with the medical knowledge to ascertain any disease. He believes himself to be the only cholera expert and uses a medication system which he considers the "best treatment known to medical science" and which "every physician worthy of the name accorded his cholera patients" (Farrell, Siege 165). He is the doctor who is "doctor-oriented and not patient-oriented" (Misselbrook 312), and his knowledge of medicine provides him with the abusive power to treat his patients the way he wants. Dunstaple supersedes McNab as an authority, not only because he is senior and more experienced but also because he has been serving the Company's personnel, without any complaints. Added to that, he is in a profession which was revered during the nineteenth century. As Christopher Lawrence writes, "In accord with the 'spirit of times', surgeons were heroes, models of the Victorian cult of manliness" (27; qtd. in Fitzpatrick 372). Dunstaple's unusual confidence is due to the delusive medical knowledge he possesses of deadly diseases like cholera.

McNab challenges his authority by espousing a different belief and method of treating cholera. It causes a division among the patients. The cholera patients are confused about whom to believe and choose for treatment. He emerges as a threat to Dunstaple's career in Krishnapur as he is a modern physician who is "known to be in 
favour of some of the most alarmingly direct methods known to civilised medicine" (Farrell, Siege 20). Unlike Dunstaple, he believes in continual observation of a patient to derive general principles regarding the mechanism of the human body. He takes note of every single development in the course of treatment of his patients and holds a more rational and scientific attitude towards physiology and diseases. David Arnold observes that colonial medicine "self-consciously conceived of itself as a science, based on careful local observation" and therefore, almost all-medical treatises of that period declare that their basis is clinical observation (Colonising the Body 18). McNab's habit of careful observation imparts his rational and scientific attitude towards the disease. Also, the paradigmatic shift brought into medical studies by the recent bacteriological research and findings shook the previous system of medicines. Not only did the indigenous system of medicine appear to be outworn but also the earlier European system of medicine that still believed in the imbalances of bodily humour and miasma met a heavy blow. It was challenging for old school doctors like Dunstaple to adapt to the new medical ideas, which $\mathrm{McNab}$ represents. According to John Spurling, "McNab is one of Farrell's "wise" doctors and represents in Krishnapur a kind of stalwart if gruff sanity based on experience, unselfish care for other people and open-minded expertise" (171).

Farrell historicises the Victorian medical debates regarding cholera. By having the doctors engage in a dialogue, he brings forth the tension within the so-called "civilised medicine" of Britain - a practice which acts as a tool of subjugation ${ }^{6}$ in the colonies during later years. Dunstaple believes that it is the "bad air" of the decaying dead bodies which has brought cholera. However, McNab possesses a very different opinion on cholera. The strife between the two doctors on the cause and treatment of cholera unpacks itself one day after the evening service is over. Dunstaple, who has been smouldering for many days, takes the opportunity of this public gathering to confront McNab, deliberately.

Use of "dialogue" as a literary form has a long history. Cunnington considers it as the "vehicle of sound knowledge and thought" (534). Plato's Symposium, and Dryden's An Essay of Dramatic Poesy (1668) are some of the best examples of it. Although it is becoming obsolete as a literary form, it is still very popular as a literary technique in novels - for instance, the dialogue between Cathy and Heathcliff in Emily Bronte's Wuthering Heights (1847), or the dialogue between Scout and Atticus in Harper Lee's To Kill a Mocking Bird (1960), etc. The dialogue technique represses the authoritative author's voice and allows the characters to open up and speak for/of themselves. Farrell very methodically brings out the dialogue between the doctors to depict prevailing nineteenth-century beliefs about cholera. Dunstaple calls upon the attention of the gathering and introduces them to McNab's belief regarding cholera, mockingly: 


\section{SARE, Vol. 57, Issue 2 | 2020}

[L]adies and gentleman, you should know that Dr McNab holds the discredited belief that you catch cholera by drinking ... more precisely, that in cholera the morbific matter is taken into the alimentary canal causing diarrhea, that the poison is at the same time reproduced in the intestines and passes out with the discharges, and that by these so-called "rice water" discharges becoming mingled with the drinking water of others the disease is communicated from one person to another continually multiplying itself as it goes. (Farrell, Siege 252)

After setting up a kind of preface to McNab's views on cholera, Dunstaple lays out his own understanding of cholera in front of the public. During the first half of the nineteenth century, the miasma theory was a predominant and accepted theory of diseases in Britain. The absence of any scientific inquiry and scholarship added credibility to this theory. The majority of medical practitioners, doctors and physicians of those times held an unshakable belief in it. The same belief guides Dunstaple. The foul smell coming from the dead bodies heaped behind the residency, acts as the base of his arguments. He emphasises that "miasma" or "bad air" causes it rather than the intake of any contaminated water. In "The Defence of Lucknow", Tennyson shows similar support to miasma theory through the lines, "Thoughts of the breezes of May blowing over an English field/Cholera, scurvy, and fever, the wound that would not be healed" (83-84).

Unwilling to yield and not ready to leave any ambiguities regarding his claims, Dunstaple goes on to describe the pathology of cholera as well as what according to him is to be done once cholera is diagnosed in a patient. The following quote, replete with descriptions of physiology as well as medical terms, fascinates the readers. It also asserts Farrell's own medical knowledge, which he developed during his engagement with doctors for a long period ${ }^{7}$. Dunstaple says:

When you inhale the poison of cholera it kills or impairs the functions of the ganglionic nerves which line the air-cells of the lungs ... hence, the vital chemistry of the lungs is suspended; neither caloric nor vital electricity is evolved ... hence, the coldness which is so typical of cholera. The blood continues to be black and carbonated ... the treacly aspect of the blood in cholera is well known ... and in due course, the heart becomes asphyxiated ... We must think of restoring the animal heat which has been lost and we must consider means of counter irritating the disease ... Hence, a warm bath, perhaps, and a blister to the spine. To relieve the pains in the head we might order leeches to the temples. An accepted method of counter-irritation in cholera is with sinapisms applied to epigastrium. (Farrell, Siege 254) 


\section{SARE, Vol. 57, Issue 2 | 2020}

For medicine, he prescribes, "brandy to support the system and pills composed of calomel, half a grain, opium and capsicum, of each one-eighth of a grain" (Farrell, Siege 254). During those times, medical practitioners used brandy, calomel, and opium for treating cholera patients. These medicines, commonly believed to cure cholera, were however, ineffective. Lack of scientific understanding of the cause and treatment of cholera enabled the colonial physicians of those times to practice this kind of medicine. Mrs R.C. Germon, who witnessed the siege personally at Lucknow residency, also mentions in her diary that opium and poultices were used in treating cholera patients. This emphasises the fact that the colonial medical understanding of diseases was not always rational. Dunstaple too practices these popular cholera treatment medicines unsuspectingly. His character aligns with the famous Victorian surgeon, later Physician Extraordinary to King Edward VII, Dr Jospeh Fayrer, who worked at the Lucknow residency during the siege. Dr Fayrer believed in the miasma theory and opined that cholera is caused by bad air. In his lifetime he never accepted the idea that germs cause cholera. By recreating his persona through Dunstaple, Farrell critiques the colonial medical authority and its understanding of disease and medicine. Sam Goodman pertinently remarks that by using such period materials, Farrell is challenging the "authority of medical and colonial history" of Britain ("Beneficial Disease" 142). By historical re-imagination Farrell foregrounds the gaps in the colonial medical system. The idea that the health of the Indians, as well as the British communities, was under a doctor who held an outdated opinion and was unreceptive of the changes in medical sciences is sobering. Howsoever it may be an individual trait or belief of Dunstaple, it forces one to look at this rigidity as an example of the utter disregard for the life of colonial subjects in particular and the broader public in general.

The further conversation between the doctors exposes the limitation of colonial medicine. After a lengthy elucidation on causes and cure of cholera, Dunstaple invites McNab to disclose his point of view, which he considers to be mere experimental quackery, in public. Again, McNab's methodical arguments laying out his opinions on diagnosis, symptoms, pathology and treatment of cholera interest the readers. However, his argument develops from the comparison of cholera with other epidemic diseases. He says:

In the greater number of epidemic diseases, the morbid poison appears to enter the blood in some way, and after multiplying during a period of so-called incubation, it affects the whole system. Such is undoubtedly the case in smallpox, measles, scarlet fever and the various kinds of continued fever ... Cholera, on the other hand, begins with an effusion of fluid into the alimentary canal, without any previous illness whatsoever. Indeed, after this fluid has begun to flow as a copious diarrhoea the 
patient often feels so little indisposed that he cannot persuade himself that anything serious is the matter. (Farrell, Siege 255)

MacNab is particular about its symptoms and knows what to do in such a situation when a patient's health deteriorates rapidly. He further says,

If you analyse the blood of someone with cholera, you'll find that the watery fluid effused into the stomachs and bowels isn't replaced by absorption ... Well the basis of my treatment of cholera is quite simply to try to restore the fluid and salts which have been lost from the blood, by injecting solutions of carbonate of soda or phosphate of soda into the blood vessels. At the same time, I try to combat the morbid action by using antiseptic agents such as Sulphur, hyposulphite of soda, creosote or camphor at the seat of the disease ... that is to say, in the alimentary canal. (Farrell, Siege 256)

Victorian British physician Dr John Snow had been critical of the miasma theory and suspected that cholera is water-borne. He had worked at Killingworth Colliery ${ }^{8}$, during the epidemics of 1832, where Dr William Hardcastle, his apprentice, sent him to treat the pitmen. He had also studied a cholera epidemic in 1853-54 in the southern districts of London, where two companies, Lambeth and Southwark \& Vauxhall, supplied water from the Thames. The two experiences helped Snow in formulating his theories on cholera transmission that he later published in his treatise On the Mode of Communication of Cholera (1855) and reports in Medical Times and Gazette. After 1857, significant measures were taken to check the supply of contaminated water. The companies filtered the faecal contaminated water before supply and used sources which were away from tidal reach of the Thames. In this regard, Davenport et al. note, "it seems very likely that these measures helped to prevent major outbreaks of water-borne diseases, except in the cholera epidemic of 1866, when regulations were breached" (408). However, Snow's claims went unrecognised for two decades.

McNab echoes Dr Snow's views on germ theory and cholera when he refutes Dunstaple's claims categorically by logical explanations. According to Binns, "The clash between the two doctors regarding the cause and proper treatment of cholera is a paradigm of the battle between the best and worst elements of the Victorian mind" (7071). The verbal duel between the doctors ends when Dunstaple kills himself. He drinks the rice-water fluid from a cholera patient to prove his claims, and consequently catches cholera and dies. Brandy and opium, the medicines he believes in, do not work to cure him. His death symbolises two things. First, it is an end to unproven medical treatments of cholera, and debunks miasma theory. Second, it hails the inception of an advanced era of medical science. Razzell aptly notes, "Although, people like Snow and Budd were groping toward an understanding of 


\section{SARE, Vol. 57, Issue 2 | 2020}

the nature and origins of diseases like cholera and typhoid, a clear understanding of the process of infection had to wait, of course, until the development of scientific bacteriology at the end of the nineteenth century" (1053).

Farrell meticulously sets up McNab as an emerging threat to Dunstaple's position as well as popularity in Krishnapur to illustrate the ambiguity and limitations of colonial medicine. To do this, he has tried to portray cholera and the medical debate "[a]s authentic and as period-specific as possible" (Goodman, "Beneficial Disease" 144). The prevalence of miasma theory and a senior doctor favouring it clearly indicates the irrational colonial perception of diseases like cholera. It suggests the lack of scientific rigour in the early Victorian medical sciences. While the British termed the India system of medicine as superstitious as we see in the novel that the Government in Calcutta regards the circulation of chapati inside the residency, which was a foretoken for an upcoming revolt, as a superstitious attempt by the Indians to avert the cholera epidemic, it is clear that their own medical understanding of diseases like cholera was unscientific. However, the forthcoming developments and changes in medical science with the advent of bacteriology were crucial in Britain's later imperial exercises. The scientific medical practices and medicines were later promoted in India for financial benefits, while simultaneously functioning as a tool in legitimating British rule in India. David Arnold rightly says, "By 1900 'topical medicine' had become vital to attempts not only to give legitimacy to Empire but also to realise its economic potential and profitability" (“Indian Ocean” 19).

Farrell's resurrection of McNab with "decades of medical experience, attempting to protect bodies from the fatal attack of disease" (McLeod 75) in his uncompleted last novel, The Hill Station (1981) set in late nineteenthcentury India, corroborates the proliferation of colonial medicine in India. McNab, whose "counter-arguments fail to convince the garrison of Krishnapur" (Goodman, "Beneficial Disease" 148) is at the end considered as the best of all by the Collector, for he was "the only one who knew what he was doing" (Farrell, Siege 312). He emerges as a medical hero in The Hill Station, as he is making observations for a treatise on Indian Medicine. Treatises of such kind ${ }^{9}$ have helped in the institutionalisation of western science and medicine in India. These treatises by European scholars have represented native healing and medical practices as superstitious, irrational, and unscientific ${ }^{10}$. In this regard, Mishra and Kumar opine that such representations were meant to "deliberately eliminate the possibilities of the role and significance of the local cultural practices of the treatment" (79).

\section{Cholera, Farrell and context: An indispensable linkage}

This section focuses on the context that situates a link between Farrell and his preoccupation with disease in general and cholera in particular. Neo-historicist critics, such as Stephen Greenblatt and Catherine Gallagher argue that every text is the product of a cultural context (7), i.e. "[N]o text appears in the world simply through 


\section{SARE, Vol. 57, Issue 2 | 2020}

the efforts of a single person, and no text is entirely disconnected from the world in which it makes its appearance" (Robson 68). In the light of this point, the discussion shows how cultural contexts, past as well as contemporary, provide a forum for Farrell's interest in the theme of the declining state of Empire, which can be clearly portrayed through an examination of the fractured medical system.

The first cholera epidemic in England erupted in Liverpool in 1832, killing hundreds of people. At that point in time, Liverpool was the principal port city of Britain and a populous centre of mercantile as well as slave trades. Friedrich Engels has described the city of Liverpool as filthy with "[s]treets generally unpaved, rough, dirty, filled with vegetable and animal refuse, without sewers or gutters but supplied with foul, stagnant pools instead" (71). Gill et al. note, "The sanitary state of Liverpool in early Victorian times was undoubtedly deplorable and probably worse than most other cities" (234). Burrell and Gill also reiterate that it was "[T]he worst of Britain's overcrowded and unsanitary cities" (480). At the beginning of the nineteenth century, many Irish immigrants populated Liverpool. These immigrants, Engels notes, lived in cellars and neglected personal and social hygiene. He further notes,

The lack of cleanliness, which is not so injurious in the country, where population is scattered, and which is the Irishman's second nature, becomes terrifying and gravely dangerous through its concentration here (Liverpool). The Milesian (Irish) deposits all garbage and filth before his house door here, as he was accustomed to do at home, and so accumulates the pools and dirt-heaps which disfigure the working- people's quarters and poison the air. He builds a pig-sty against the house wall as he did at home, and if he is prevented from doing this, he lets the pig sleep in the room with himself. (81)

This wave of immigration, estimated by Waller (1981) to be around half a million people during the first half of the nineteenth century, was crucial in spreading the cholera epidemic. Lack of cleanliness, inadequate supply of clean water, improper disposal of sewage and absence of personal hygiene among the people in Liverpool escalated the epidemic. A disturbance, famously known as the "cholera riots of Liverpool" followed the outbreak, which led to a clash between medical professionals and the public, and attacks at dispensaries and hospitals. The British Parliament passed a "Cholera Morbus Prevention Act" to ensure strict cleanliness and hygiene in the state during that time. Nevertheless, Liverpool again suffered significant cholera outbreaks at least three more times, in 1848,1853 and 1861 . The devastation caused by cholera in terms of human death was particularly high in Liverpool, as compared to all other cholera cases that occurred in Britain until 1855. According to Underwood, 
in the epidemic of 1832, the number of deaths was 1,523, in the outbreak of 1848-49, the number of deaths was 5,308 , and in the outbreak of 1853-54, the number of deaths was 1,084.

The epidemic in Liverpool and the later developments that followed are crucial in the history of cholera in Britain. No British writer researching on cholera can overlook the Liverpool incident. Interestingly, Farrell was born in Liverpool in 1935, approximately one hundred years after the beginning of cholera epidemics in England. His father and grandfather also were natives of Liverpool. Undoubtedly, Farrell's background is his muse for historicising cholera. In this regard, Malcolm Dean notes that cherished old books and volumes of nineteenthcentury British Medical Journal were at his (Farrell's) disposal where he found accounts of the "blow by blow battle within the medical world on the cause of cholera, which he later made use of in Krishnapur" (197).

The influence of the Liverpool cholera epidemic is apparent in the novel. There are similarities between the cholera-ridden Liverpool and the residency of Krishnapur on multiple levels. Both are crowded places marked with uncleanliness and unsanitary living conditions, gripped by a cholera epidemic. The filthy population of Liverpool is mirrored in the besieged community of Krishnapur residency. The dense population of Liverpool, which exacerbated the spread of the contagious epidemic, is similar to the dense population of the residency. The influx of Irish immigrants into Liverpool parallels the influx of the European and Eurasian community into the residency, which increased population pressure inside the residency. Both are in a perpetual state of siege from within and outside. Burrell and Gill mention an actual, suspected case of cholera in Liverpool, which the Liverpool Journal published on 5 May 1832.

Yesterday there were loud whispers through the town of the cholera having arrived in Liverpool ... The case in Bachelor-street was that of a young man named Murphy. He had been drinking hard, we understand, the preceding night, and though unwell yesterday morning he went out to his work. He was soon, however, compelled to return, and was seized with spasms; purging and vomiting ensued, and he died yesterday at seven o'clock. (482)

The symptoms of cholera include persistent spasms and vomiting. In the novel, Dr McNab has recorded similar symptoms in his wife, who died of cholera. He records "She has persistent cramps and vomits constantly a thin, gruel-like fluid without odour" (Siege 166) which parallels the actual cholera case of Liverpool. All these similarities are signposts that connect the dots between Liverpool and Farrell's fictional residency.

Another connection between cholera and Farrell comes from French author Albert Camus. By the time Farrell started working in France as a teacher, Camus had published his major works. In Farrell's early novels, references to Camus' works are explicit (McLeod 11). Again, The Siege of Krishnapur bears a resemblance to 
Camus' classic novel, The Plague (1947), in many ways. One can draw similarities on multiple counts, such as theme, character portrayal and setting. The residency of Krishnapur resembles the city of Oran. The two towns, both suffering extremely hot weather, are entrapped in epidemics. The character of Father Paneloux in The Plague is similar to that of Mr Hampton, the Padre in The Siege of Krishnapur. Lavinia Greacen remarks that Farrell's "original ambition was to match the achievement of Camus in Le Peste (The Plague), with which The Siege of Krishnapur shares a strong moral base" (380). Besides, the influence of Camus' existential philosophy is very prominently present in the novel where the siege acts as a "microcosm of human life and human condition" (qtd. in Binns 18). The besieged in the residency are in a perpetual struggle for life: illness, gloominess, and infirmity of human life pervade the novel.

The period from the 1960 s to 1970 s is very crucial in the history of cholera research. There have been six big cholera pandemics since 1817, so far killing millions of people across the globe. The seventh cholera pandemic was identified in 1961, and from 1961 to 1972, cholera was a much-discussed issue in the contemporary medical scholarship. A few significant historical studies on cholera epidemics across the world appeared during this period. Louis Chevalier's The Cholera: The first epidemic of Nineteenth Century (1958), Roderick McGrew's Russia and the Cholera, 1823-1832 (1960), Asa Briggs' "Cholera and Society in the Nineteenth Century" (1961), Charles Rosenberg's The Cholera Years: The United States in 1832, 1849, and 1866 (1962) are some of the remarkable studies that prominently feature cholera epidemics. During the same time, "medical humanities" emerged as an interdisciplinary field of study, and programs on medical humanities were started in medical schools (Brody 1). Paul Ramsey's influential text on medical humanities, The Patient as a Person, appeared in 1970. According to Sam Goodman, "Farrell's literary critique of Empire corresponds with the contextual emergence of the medical humanities" ("Beneficial Disease” 145). Farrell's recreation of a historical medical discourse with fictional characters sets the novel as a fine example of this discipline, which attempts to further the understanding of medical science through literature. According to Carson, the discipline developed when "authority and expertise were being questioned, and traditional ways of doing things were being challenged" (322). Farrell's novel gives his reader a glimpse of such a situation, where the expertise and authority of a senior doctor in the treatment of cholera is questioned and challenged by a junior doctor. The novel, loaded with medical cases lets its readers visualise the subjective experiences of patients, which not only provides them with the knowledge of how disease adversely affects the lives of the patients as well of their caretakers, but also enables readers to empathise with such patients in real life. For instance, the condition of the ailing Collector is mentioned as follows: 


\section{SARE, Vol. 57, Issue 2 | 2020}

The illness had aged him. He lay still for hour after hour, naked beneath a sheet because of the heat and humidity, the mosquito net cast aside for air, too exhausted even to lift an arm to drive away the mosquitoes which constantly settled on his face. Miriam or one of the older children of the garrison who could no longer play outside since the shrinking of the perimeter sat constantly at his bedside to fan him and to defend him against the mosquitoes. He said nothing. He seemed too exhausted even to speak or move his eyes. (Farrell, Siege 226)

Miriam is horrified to see her father's deteriorating medical condition, later. Farrell writes, "Miriam knew that people can die of erysipelas and when she saw what a state the Collector was in, rolling on the floor in delirium, his face red and swollen, she received an unpleasant shock" (Siege 218). This entire cultural context suggests Farrell's motivation for writing about cholera.

One of the five fundamental assumptions about New Historicism suggested by H. A. Veeser is that a text is always "embedded in a network of material practices". Further, the "literary and non-literary texts circulate inseparably" (Veeser 2). Publication of this novel in 1973 interacts with other contemporary cultural developments. The context establishes an interface between Farrell and Cholera. In one of his interviews, Farrell remarked, "It seemed to me that the really interesting thing that's happened during my lifetime has been the decline of the British Empire" (qtd. in Binns 16). Therefore, when Farrell decided to write about the declining empire, setting his story in 1857 , there could not have been a more appropriate subject than cholera to serve many of his purposes. "[C]holera violated imperial expectations, countered enlightened ideals of progress, and challenged scientific rationality" (Almeida 60). According to Binns, medical debates on cholera are one of the significant "moments in history which involved blows to imperial self-esteem and a loss of cultural selfconfidence" (Binns 17). Thus, by contextualising cholera in a historical episode, Farrell uses it as a tool to excavate Victorian medical debates on cholera.

\section{Conclusion}

Varied opinions on the root cause of cholera and its treatment are visible in the early nineteenth century, due to a lack of empirical evidence. This paper has discussed how Farrell has historicised the whole medical debate through the strife between the two doctors stationed at Residency. Although as Greacen remarks he was "well equipped to write about the spread of potentially fatal disease" (381), it is surprising as well as of merit to appreciate the way Farrell describes the minute details of cholera and its victims in the novel, as if he were a doctor by profession or had some training in medical practice. The article then has argued how Farrell's critique 
of an outdated medical theory and simultaneous welcoming of the scientific future of British medicine is an attempt to reinstate the position of "civilised medicine" in colonial India; it is presented as more scientific and empirical, hence, superior to native medical practices. The resurrection of $\mathrm{McNab}$, in his posthumous novel, is a testimony to this. Farrell is very much a product of his age. The 1960s context shapes his consciousness and creativeness, and that gets reflected in his novel. The paper has unravelled a relationship between Farrell and cholera and has shown how cholera is part and parcel of his thought process when his biographical account and the contemporary context are placed side by side.

\section{Notes}

1. The first is Troubles (1970), and the last is The Singapore Grip (1978).

2. A residency (similar to district) was a classified territory for ease of administration. The Residency system was prevalent in India during the Company's time. The colonial administrators, also known as "Residents", representatives of the East India Company, resided in the Residency, which acted as control office for the territory. The Residents took their orders from the respective presidencies (Bengal, Bombay, and Madras) and were answerable to the respective Governors. Lucknow was one of the residencies of the Company. For more see: Fisher's “Indirect Rule in the British Empire: The Foundations of the Residency System in India (1764-1858)" (1984), Johnson's "What was the nature of British rule in India, c.17701858?” (2003), James Onley’s “The Raj reconsidered: British India's informal empire and spheres of influence in Asia and Africa (2009).

3. There is a contention on the name of the movement. It is otherwise known as the Sepoy Mutiny of 1857 , or Indian Uprising of 1857. See: S. N. Sen’s Eighteen fifty-seven (1957) and Crispin Bates and Marina Carter "An Uneasy Commemoration: 1957, the British in India and the "Sepoy Mutiny" in Mutiny at the Margins: New Perspectives on the Indian Uprising of 1857 edited by Crispin Bates, SAGE, 2014, pp. 115-137.

4. Miasma, also known as "bad air" was a disease theory prevalent actively until the 1850 s. According to it, when the air contains poisonous decaying matter, i.e. miasma, it causes diseases and epidemics.

5. The other two are smallpox and plague.

6. See MacLeod \& Lewis', Disease Medicine and Empire (1988), Arnold's Imperial Medicine and Indigenous Societies (1988), Bynum's Science and Practice of Medicine in the Nineteenth Century (1994), Browns' “A Tool of Empire: The British Medical Establishment in Lagos 1861-1905” (2004).

7. See Lavinia Greacen's J.G. Farrell: The Making of a Writer (2000) for more details on his medical history. 


\section{SARE, Vol. 57, Issue 2 | 2020}

8. Killingworth Colliery was one of the most affected places during the cholera epidemic of 1832 . This place had many coal mines and hundreds of pitmen working underground. During the pandemic, many pitmen working underground died.

9. E.g. Health Problems of the Empire: Past, Present and Future (1924) by Andrew Balfour and H. H. Scott. 10. Ghosh, in The Calcutta Chromosome, has used subversive strategies to critique such representations.

\section{Works Cited}

Almeida, João Rangel. "Epidemic Opportunities: Panic, Quarantines, and the 1851 International Sanitary Conference." Empires of Panic: Epidemics and Colonial Anxieties, edited by Robert Peckham, Hong Kong UP, 2015, pp. 57-86.

Arnold, David. Colonising the Body: State Medicine and Epidemic Disease in Nineteenth Century India. U of California P, 1993.

---, editor. Imperial Medicine and Indigenous Societies. Manchester UP, 1988.

---. “The Indian Ocean as a disease zone, 1500-1950.” South Asia: Journal of South Asian

Studies, vol.14, no.2, 1991, pp. 1-21.

Beattie, James. "Health Panics, Migration and Ecological Exchange in the Aftermath of the 1857 Uprising: India, New Zealand, and Australia." Empires of Panic: Epidemics and Colonial Anxieties, edited by Robert Peckham, Hong Kong UP, 2015, pp. 87-110.

Binns, Ronald. J .G. Farrell. Methuen, 1986.

Burrell, Sean, and Geoffrey Gill. "The Liverpool Cholera Epidemic of 1832 and Anatomical Dissection Medical Mistrust and Civil Unrest." Journal of the History of Medicine and Allied Sciences, vol. 60, no.4, 2005, pp. 478-498.

Carson, Ronald A. "Engaged Humanities: Moral Works in the Precincts of Medicine." Perspectives in Biology and Medicine, vol. 50, no. 3, 2007, pp. 321-333.

Collingham, Elizabeth M. Imperial Bodies: The Physical Experience of the Raj, 1800-1947. Polity Press, 2001.

Crane, Ralph, and Jennifer Livett. Troubled Pleasures: The Fiction of JG Farrell. Four Courts, 1997.

Cunnington, S. "Dialogue as a literary form." New Blackfriars, vol. 3, no. 33, 1922, pp. 534-542.

Davenport, Romola, et al. "Cholera as a 'sanitary test' of British cities, 1831-1866." The History of the Family, vol. 24, no. 2, 2019, pp. 404-438. 


\section{SARE, Vol. 57, Issue 2 | 2020}

Dean, Malcolm. “A Personal Memoir.” The Hill Station and an India Diary, edited by John Spurling,

Weidenfeld \& Nicolson, 1981, pp. 192-206.

Engels, Friedrich. The Condition of the Working Class in England, Penguin Books, 1844/1987.

Farrell, James G. The Hill Station, Weidenfeld \& Nicolson, 1981.

---. The Siege of Krishnapur, Phoenix, 1973/2007.

Fitzpatrick, Kieran. "Surgery, Imperial Rule and Colonial Societies (1800-1930): Technical, Institutional and

Social Histories." The Palgrave Handbook of the History of Surgery, edited by Thomas Schlich,

Palgrave Macmillan, 2017, pp. 369-387.

Foucault, Michael. The Birth of the Clinic: An Archeology of Medical Perception. Translated by A.M.

Sheridan, Routledge, 1963/2003.

Gallagher, Catherine, and Stephen Greenblatt. Practicing New Historicism. U of Chicago P, 2000.

Germon, Maria Vincent. A Diary kept by Mrs. R. C. Germon at Lucknow between the months of May and December, 1857. Pickle Partners, 1870/2014.

Ghosh, Amitav. The Calcutta Chromosome. Penguin Books, 1995/2009.

Gilbert, Pamela K. Cholera and Nation: Doctoring the Social Body in Victorian England. State U of New York P, 2008.

Gill, Geoffrey, et al. "Fear and Frustration: The Liverpool Cholera riots of 1832." The Lancet, no. 358, 2001, pp. 233-237.

Goodman, Sam. “A Great Beneficial Disease: Colonial Medicine and Imperial Authority in J. G. Farrell's The Siege of Krishnapur." Journal of Medical Humanities, vol. 36, no. 2, 2014, pp. 141-156.

---. "Unpalatable Truths: Food and Drink as Medicine in Colonial British India." Journal of History of Medicine and Allied Sciences, vol. 73, no. 2, 2018, pp. 205-222.

Greacen, Lavinia. "Commentary: 'As cholera began its measured advance through the garrison ..."” International Journal of Epidemiology, vol. 42, 2013, pp. 380-381.

Hamlin, Cristopher. Cholera: The Biography. Oxford UP, 2009.

Harrison, Mark. "Tropical Medicine in Nineteenth-Century India." The British Journal for the History of Science, vol. 25, no. 3, 1992, pp. 299-318.

---. Public Health in British India: Anglo-Indian Preventive Medicine 1859-1914. Cambridge UP, 1994.

Henty, George A. In Times of Peril: A Tale of India. Griffith and Farran, 1881.

Karamanou, Marianna, et al. "From Miasmas to Germs: A Historical Approach to Theories of Infectious Disease Transmission." Infez Med, vol. 20, no. 1, 2012, pp. 58-62. 


\section{SARE, Vol. 57, Issue 2 | 2020}

Kumar, Deepak. “Medical Encounters in British India 1820-1920.” Economic and Political Weekly, vol. 32, no. 4, pp. 166-170.

Lawrence, Christopher. "Democratic, Divine and Heroic: The History and Historiography of Surgery.” Medical Theory, Surgical Practice: Studies in the History of Surgery, edited by Christopher Lawrence, Routledge, 1997, pp. 1-47.

Lee, Kelley. "The Global Dimensions of Cholera.” Global Change and Human Wealth, vol. 2, no.1, 2001, pp. 6-17.

Lester, Alan. "Empire and the Place of Panic." Empires of Panic: Epidemics and Colonial Anxieties, edited by Robert Peckham, Hong Kong UP, 2015, pp. 23-35.

MacLeod, Roy and Milton Lewis, editors. Disease, Medicine and Empire: Perspectives on Western Medicine and the Experience of European Expansion. Routledge, 1988.

Majumdar, Ramesh C. The Sepoy Mutiny and the Revolt of 1857. Calcutta Oriental, 1957.

McCleery, Iona. "What is 'colonial' about medieval colonial medicine? Iberian health in global context." Journal of Medieval Iberian Studies, vol. 7, no. 2, 2015, pp. 151-175.

McLeod, John. "Exhibiting Empire in JG Farrell's The Siege of Krishnapur.” The Journal of Commonwealth Literature, vol. 29, no. 2, 1994, pp. 117-132.

---. J.G. Farrell. Northcote House Publishers, 2007.

Mishra, Sanjit and Nagendra Kumar. "Shaking the Roots of Western Science in Amitav Ghosh's The Calcutta Chromosome." Asiatic, vol. 5, no. 1, 2011, pp. 78-85.

Misselbrook, David. "Foucault”. The British Journal of General Practice, vol. 63, no. 611, 2013,p. 312.

Morrell, Jack B. "Individualism and the Structure of British Science in 1830." Historical Studies in the Physical Science, vol. 3, 1971, pp. 183-204.

Mushtaq, Muhammad U. "Public health in British India: A brief account of the history of medical services and disease prevention in colonial India.” Indian Journal of Community Medicine, vol. 34, no. 1, 2009, pp. 6-14.

Platizky, Roger S. “Tennyson and Cholera.” Victorian Poetry, vol. 35, no. 4, 1997, pp. 533-542.

Pollitzer, Robert. "Cholera Studies: History of the Disease.” Bulletin World Health Organization, vol. 10, no. 3, 1954, pp. 421-461.

Ramasubban, Radhika. Public Health and Medical Research in India: Their Origins, and Developments under the Impact of British Colonial Policy. SAREC, 1982. 


\section{SARE, Vol. 57, Issue 2 | 2020}

---. "Imperial Health in British India: 1857-1900." Disease, Medicine and Empire: Perspectives on

Western Medicine and the Experience of European Expansion, edited by R. Macleod and M. Lewis, Routledge, 1988, pp. 38 - 60.

Razzell, Peter. "Review of Cholera, Fever, and English Medicine, 1825-1865 by Pelling Margaret." The American Historical Review, vol. 84, no. 4, 1979, p. 1053.

Robson, Mark. Stephen Greenblatt. Routledge, 2008.

Rosenberg, Charles E. "Medicine and Community in Victorian Britain." The Journal of Interdisciplinary History, vol. 11, no. 4, 1981, pp. 677-684.

Saini, Anu. "Physicians of Colonial India (1757-1900)." Journal of Family Medicine and Primary Care, vol. 5, 2016, pp. 528-32.

Spurling, John. "As Does the Bishop.” The Hill Station and an India Diary, edited by John Spurling,

Weidenfeld \& Nicolson, 1981, pp. 155-177.

Tennyson, Alfred L. "The Defence of Lucknow, 1879." https://www.bartleby.com/297/629.html Accessed 10 June 2020.

Thorpe, Michael. "Making History: Fiction, History and the Indian 'Mutiny'." World Literature Written in English, vol. 26, no. 1, 1986, pp. 179-187.

Underwood, E. Ashworth. "The History of Cholera in Great Britain." Proceedings of the Royal Society of Medicine, vol. 41, no. 3, 1948, pp. 165-173.

Veeser, Harold Aram, editor. The New Historicism Reader. Routledge, 1994.

Wakimura, Kohei. "Globalisation, Environment and Epidemic Disease: Cholera in $19^{\text {th }}$ Century. Asia.XIV International Economic History Congress Helsinki, Session 46, 2006. http://www.helsinki.fi/iehc2006/papers2/Wakimura.pdf. Accessed 25 May 2020.

Waller, Philip J. Democracy and Sectarianism: A Political and Social History of Liverpool, 1868-1939. Liverpool UP, 1981. 